\title{
$\alpha$-Bungarotoxin Binding to Hippocampal Interneurons: Immunocytochemical Characterization and Effects on Growth Factor Expression
}

\author{
Robert Freedman, ${ }^{1,2}$ Cynthia Wetmore, ${ }^{1}$ Ingrid Strömberg, ${ }^{1}$ Sherry Leonard, ${ }^{2}$ and Lars Olson ${ }^{1}$ \\ 'Department of Histology and Neurobiology, Karolinska Institute, Stockholm, Sweden S-10401 and '2Departments of \\ Psychiatry and Pharmacology, Denver Veterans Administration Medical Center and University of Colorado Health \\ Sciences Center, Denver, Colorado 80262
}

\begin{abstract}
The nicotinic cholinergic antagonist $\alpha$-bungarotoxin ( $\alpha$-BT) binds throughout the rat hippocampal formation. The binding is displaceable by $d$-tubocurarine. The most heavily labeled cells are GABA-containing interneurons in the dentate and in Ammon's horn. These neurons have several different morphologies and contain several neuropeptides. $\alpha$-BT-labeled interneurons in the dentate are small cells between the granular and molecular layers that often contain neuropeptide $Y$. $\alpha-B T-$ labeled interneurons in CA1 are medium-sized interneurons, occasionally found in stratum pyramidale, but more often found in stratum radiatum and stratum lacunosum moleculare. These neurons often contain cholecystokinin. The largest $\alpha$-BT-labeled interneurons are found in CA3, in both stratum radiatum and stratum lucidum. These neurons are multipolar and frequently are autofluorescent. They often contain somatostatin or cholecystokinin. These large interneurons have been found to receive medial septal innervation and may also have projections that provide inhibitory feedback directly to the medial septal nucleus. The cholinergic innervation of the hippocampus from the medial septal nucleus is under the trophic regulation of NGF and brainderived neurotrophic factor, even in adult life. Expression of mRNA for both these factors is increased in CA3 and the dentate after intraventricular administration of $\alpha$-BT, but not after administration of the muscarinic antagonist atropine. $\alpha$-BT-sensitive cholinergic receptors on inhibitory interneurons may be critical to medial septal regulation of the hippocampal activity, including the habituation of response to sensory input.
\end{abstract}

IKey words: bungarotoxin, hippocampus, interneurons, NGF, brain-derived neurotrophic factor, cholecystokinin, somatostatin, neuropeptide $Y$, nicotinic receptors]

Medial septal innervation of the hippocampus has been associated with a number of functions of the hippocampus, including generation of the theta rhythm (Vanderwolf, 1975), short-term

\footnotetext{
Received Apr. 2, 1992; revised Oct. 30, 1992; accepted Nov. 13, 1992.

This research was supported by the Medical Research Council of Sweden, the Veterans Administration Medical Research Service, and National Institute of Mental Health Awards MH-44212 and MH-38231. We thank Monica Nyman, Eva Lindquist, Dorothy Dill, and Susanne Almerström for technical assistance. Laura Lee Lamothe prepared the manuscript.

Correspondence should be addressed to Robert Freedman, M.D., Department of Psychiatry C-268-71, University of Colorado Health Sciences Center, 4200 East Ninth Avenue, Denver, CO 80262.
}

Copyright $@ 1993$ Society for Neuroscience $0270-6474 / 93 / 131965-11 \$ 05.00 / 0$ memory (Lippa et al., 1980), modulation of seizure threshold (Green et al., 1989; Marks et al., 1989), and habituation of response to sensory stimuli (Vinogradova, 1975). The importance of this pathway is emphasized by its apparent trophic regulation by several growth factors, including NGF and brainderived neurotrophic factor (BDNF), even in adult life (Korsching et al., 1985; Phillips et al., 1990). Cholinergic neurotransmission involves a diverse set of postsynaptic receptors and mechanisms. The G-protein-coupled muscarinic receptors are closely associated with cholinergic generation of the theta rhythm (Vanderwolf, 1975) and short-term memory (Lippa et al., 1980). These functions are also primarily associated with the CA1 area. Muscarinic receptors are more concentrated in this area and relatively less dense in CA3 and the dentate (Joyce et al., 1989).

Seizure genesis and habituation of response to sensory stimuli have been linked to nicotinic mechanisms (Marks et al., 1989; Luntz-Leybman et al., 1992). These functions are closely associated with the CA3 field (Schwartzkroin, 1986; BickfordWimer et al., 1990). Nicotinic responses are mediated by two major classes of receptors, ganglionic type and neuromuscular type. Pharmacological analysis of both seizure genesis and habituation in rat brain implicates mediation by a neuromuscular type (Miner and Collins, 1989; Luntz-Leybman et al., 1992). These data are supported by the prominent binding of the neuromuscular-type antagonist $\alpha$-bungarotoxin $(\alpha-\mathrm{BT})$ in the CA3 field of the hippocampus (Hunt and Schmidt, 1978; Segal el al., 1978; Clarke et al., 1985; Härfstrand et al., 1988; Pauly et al., 1989). The ganglionic antagonist called neuronal or $\kappa$-BT also binds in CA3, but the binding is fully displaced by $\alpha$-BT (Schulz et al., 1991). In most other brain areas, there is no such displacement. The binding data are supported by in situ hybridization for several of the $\alpha$-subunits of the nicotinic receptor. $\alpha$-Subunits 2, 3, and 4 form receptors that are sensitive to neuronal BT and other ganglionic antagonists (Boulter et al., 1987). cDNA probes for these subunits do not hybridize strongly in the hippocampus (Wada et al., 1989). However, a probe for the $\alpha 7$ subunit, which produces an $\alpha$-BT-sensitive receptor, hybridizes strongly in the hippocampus (Johnson et al., 1991).

The identity of hippocampal neurons that bind $\alpha$-BT would seem to be critical for further understanding of the role of nicotinic neurotransmission in hippocampal function. Although $\alpha-\mathrm{BT}$ binding in the hippocampus has already been demonstrated by a number of investigators, there have been few studies that have extended these findings to the cellular level. In one study at the ultrastructural level, $\alpha$-BT was found to bind near 

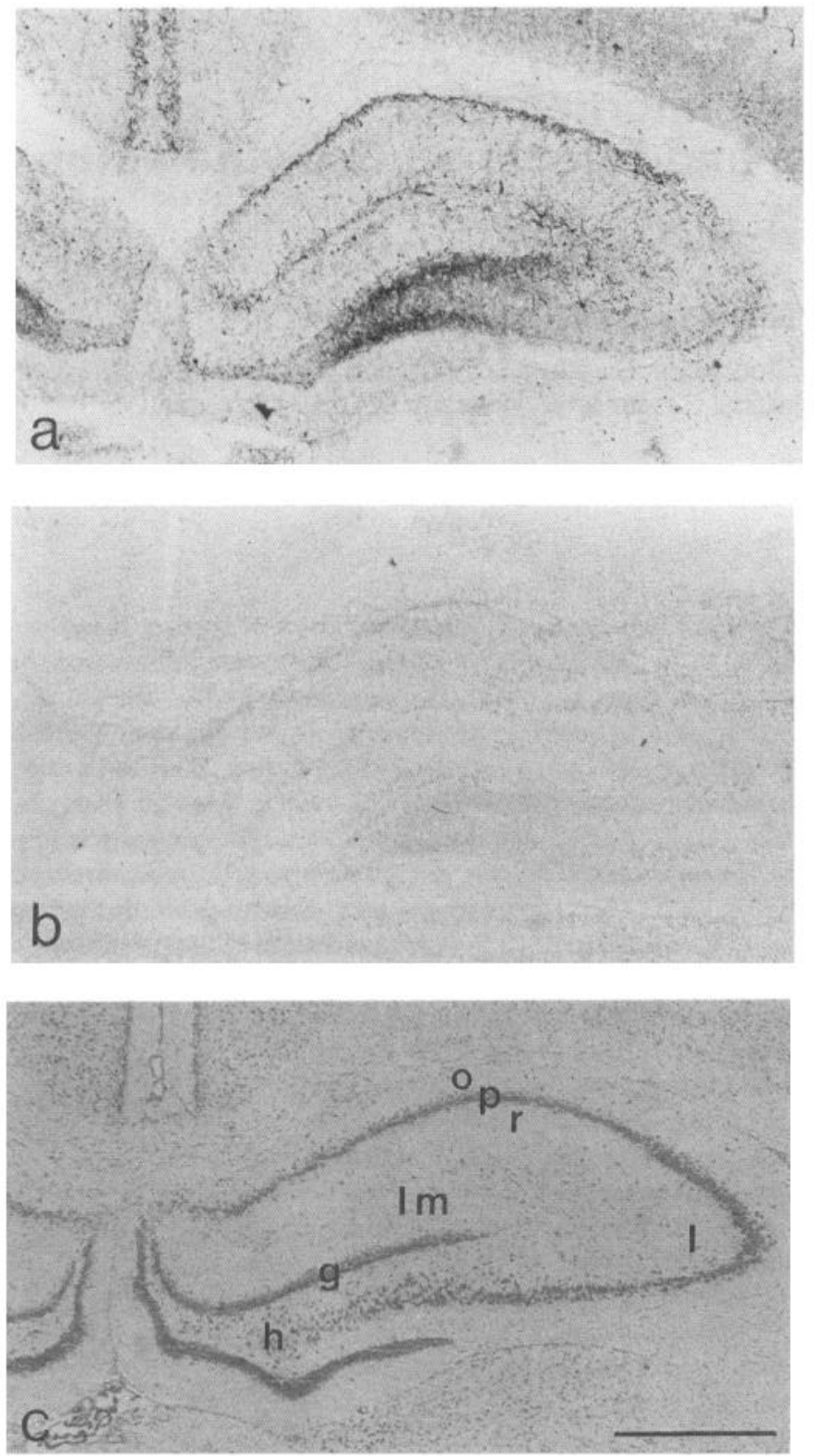

Figure 1. Binding of ${ }^{125} \mathrm{I}-\alpha$-BT in rat brain. $a$ shows a pattern of binding to frozen rat brain sections. $b$ shows binding with the same concentration of ${ }^{125} \mathrm{I}-\alpha$-BT, blocked in the presence of $10^{-4} \mathrm{M} d$-tubocurarine. $c$ is a cresyl violet-stained section. In this and subsequent figures, the following abbreviations are used: stratum oriens $(o)$, stratum pyramidale $(p)$, stratum radiatum $(r)$, stratum lacunosum moleculare $(l m)$, stratum lucidum $(l)$, dentate granule cells $(g)$, and hilus $(h)$. Scale bar, $1 \mathrm{~mm}$.

synapses of both pyramidal and nonpyramidal neurons (Hunt and Schmidt, 1978). Both types of neurons receive cholinergic innervation (Frotscher and Leranth, 1985). The aim of the present study was to identify the nonpyramidal neurons that bind $\alpha$-BT. Autoradiographic localization of ${ }^{125} \mathrm{I}-\alpha-\mathrm{BT}$ and immunocytochemical detection of GABA were used to identify a population of interneurons that have $\alpha$-BT-sensitive receptors. Interneurons of the hippocampus contain a variety of neuropeptides, including cholecystokinin (CCK; Sloviter and Nilaver, 1987), neuropeptide Y (NPY; Deller and Leranth, 1990), and somatostatin (Kohler and Chan-Palay, 1982). Simultaneous $\alpha$-BT binding and immunohistochemistry were also used to determine the possible overlap between the presence of $\alpha$-BTbinding proteins and these neuropeptides.

Because of the importance of the NGF family to the integrity of the cholinergic medial septal pathway, in situ hybridization was used to determine the effects of $\alpha$-BT on mRNA expression of several growth factors in hippocampal neurons. Lesion of the fornix increases the expression of NGF in hippocampal neurons (Ayer-LeLievre et al., 1988). However, treatment with the muscarinic cholinergic antagonist scopolamine does not increase levels of NGF in the hippocampus (Alberch et al., 1991). In the present study, the effects of $\alpha$-BT and atropine were compared on expression of the message for NGF, BDNF, and hippocampal-derived neurotrophic factor or neurotrophin-3 (NT3).

\section{Materials and Methods}

$\alpha$-BT binding. $\alpha$-BT binding was performed in four animals by the protocol of Fuchs (1989). Male rats $(150 \mathrm{gm})$ were obtained from Alab (Stockholm, Sweden). Animals were anesthetized with pentobarbital and the brain was rapidly removed and frozen on a $\mathrm{CO}_{2}$ freezing stage. Fourteen-micrometer cryostat sections, thaw mounted on slides coated with poly-L-lysine, were incubated for $1 \mathrm{hr}$ at room temperature in a solution containing $5 \mathrm{~nm}{ }^{125} \mathrm{I}-\alpha$-BT (specific activity, $2000 \mathrm{Ci} / \mathrm{mmol}$; Amersham) in $1.25 \%$ bovine serum albumin, $0.05 \mathrm{M}$ Tris $\mathrm{HCl}, \mathrm{pH} 7.4$. This concentration of $\alpha$-BT has been found to saturate a single class of receptors (Clarke et al., 1985). Preincubation for $30 \mathrm{~min}$ in $10^{-4} \mathrm{M}$ $d$-tubocurarine was used to detect nonspecific binding. After incubation with $\alpha$-BT, the slides were washed in ice-cold buffer for $15 \mathrm{~min}$, followed by three $15 \mathrm{~min}$ washes in ice-cold distilled water. The slides were then dehydrated in $70 \%$ and $95 \%$ ethanol, dried, and dipped in autoradiographic emulsion diluted 1:1 in water (NTB-2, Kodak, Rochester, NY). After a $10 \mathrm{~d}$ exposure at $-20^{\circ} \mathrm{C}$, the slides were developed in Kodak D-19 diluted 1:1 in water, fixed, counterstained with cresyl violet, and coverslipped.

Four animals received $\alpha$-BT in vivo. These animals were anesthetized with pentobarbital and placed in a stereotaxic instrument. ${ }^{125} \mathrm{I}-\alpha-\mathrm{BT}$, $0.01 \mathrm{mCi}$, was injected into the lateral ventricle, and the animal was allowed to survive for $30 \mathrm{~min}$. This time was chosen because it is the interval at which maximal effects of $\alpha$-BT on electrophysiological responses in hippocampus are observed (Luntz-Leybman et al., 1992). The animals were then perfused for immunocytochemistry, followed by autoradiography, as described below.

Immunocytochemistry. Six animals were anesthetized with pentobarbital and then perfused through the aorta with calcium-free Tyrode's solution, followed by $4 \%$ paraformaldehyde with $0.4 \%$ picric acid in $0.1 \mathrm{~m}$ phosphate buffer, $\mathrm{pH}$ 7.0. The brain was blocked and immersed in the fixative for several hours and then rinsed overnight in $10 \%$ sucrose in $0.1 \mathrm{~m}$ phosphate buffer. Cryostat sections $(14 \mu \mathrm{m})$ were collected on chrom-alum-treated slides, rinsed in phosphate-buffered saline (PBS), and then incubated overnight at $4{ }^{\circ} \mathrm{C}$ in a humidified chamber with primary antibody diluted in PBS containing $0.3 \%$ Triton. Sections were rinsed twice in PBS and then exposed for $1 \mathrm{hr}$ at room temperature to a species-specific fluorescein-labeled secondary antibody. The slides were then coverslipped with $90 \%$ glycerin in PBS, with $0.1 \%$-phenylene diamine as an antifading agent.

Primary antibodies and dilutions used were anti-GABA (guinea pig, 1:200; Sequala et al., 1984), anti-CCK (rabbit, 1:1000; Abbott, Chicago, IL), and anti-NPY (rabbit, 1:400; Peninsula, Belmont, CA). A mouse monoclonal antibody for somatostatin $(1: 400)$ was a gift from Prof. T. Hökfelt. Control slides were reacted only with secondary antibody.

Immunoreactive neurons in the hippocampus were photographed under epi-illumination. The coverslips were then removed and the slides were exposed to ${ }^{125} \mathrm{I}-\alpha$-BT as described above, except for slides from animals that had previously received ${ }^{125} \mathrm{I}-\alpha$-BT intraventricularly. After autoradiographic exposure and counterstaining with cresyl violet, the slides were examined for correspondence between neurons labeled with $\alpha$-BT and those that had been previously found to be immunoreactive.

In situ hybridization. Animals were anesthetized briefly with halothane and placed in a stereotaxic apparatus. Intraventricular injection of $\alpha$-BT ( $1 \mu \mathrm{g}$, two animals, or $0.3 \mu \mathrm{g}$, three animals), or atropine sulfate $(1 \mu \mathrm{g}$, two animals) was performed. Both drugs were obtained from Sigma Chemical (St. Louis, MO). Assuming a ventricular volume of $100 \mu \mathrm{l}$, final concentrations were $300 \mathrm{nM}$ to $1 \mu \mathrm{M}$ for $\alpha$-BT and $1.4 \mu \mathrm{M}$ 

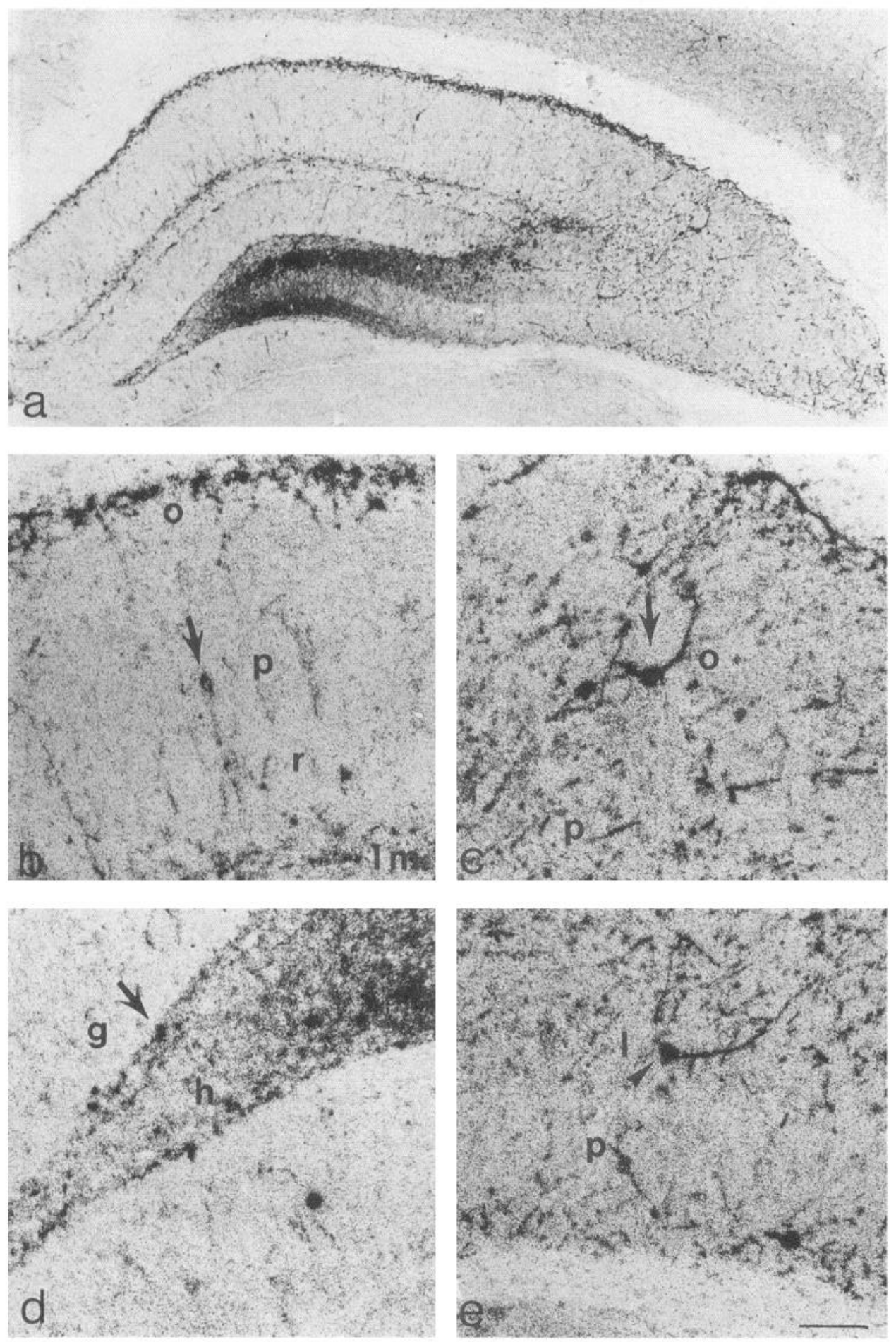

Figure 2. Binding of ${ }^{125} \mathrm{I}-\alpha-\mathrm{BT}$ to a frozen section of rat hippocampus $(a)$ In the CA1 region $(b)$, there are small labeled neuronal cell bodies in the distal portion of stratum oriens, near the alveus, as well as some labeled cells in stratum lacunosum moleculare. There are also occasional small cells (arrow) labeled within stratum pyramidale. In the $\mathrm{CA} 3$ region $(c, e)$, there are larger cells (arrows) labeled in stratum oriens $(c)$ and in stratum lucidum $(e)$. Labeling in the dentate gyrus $(d)$ is heaviest in small cells (arrow) located at the edges of the granular layer. Scale bar, $50 \mu \mathrm{m}$. for atropine sulfate. Animals were matched with controls that received injections of the same volume of Ringer's solution $(10 \mu \mathrm{l})$, as well as with unoperated animals. A $3 \mathrm{hr}$ survival interval was chosen on the basis of reports that nonspecific effects of the injection procedure itself on growth factor mRNA expression are no longer present by that time (Ballarin et al., 1991). The animals were then anesthetized with pentobarbital, and the brains were removed and frozen. Cryostat sections $(14 \mu \mathrm{m})$, thaw mounted on poly-L-lysine-coated slides, were used for hybridization.

In situ hybridization was performed using synthetic 50-mer oligonucleotide probes, 3 '-end labeled with ${ }^{35} \mathrm{~S}$-dATP(New England Nuclear, Boston, MA). Probes were constructed for NGF (nucleotides 868-918 in Whittemore et al., 1988), BDNF (Wetmore et al., 1991), and NT3 (nucleotides 667-717 in Ernfors et al., 1990). The probes were selected to hybridize with unique sequences in each of the different rat growth factor sequences. A probe for rat NGF receptor with similar GC content was used to control for nonspecific hybridization. The sections were hybridized $15 \mathrm{hr}$ at $42^{\circ} \mathrm{C}$ in a solution containing $50 \%$ formamide, $4 \times$ saline-sodium citrate (SSC), $1 \times$ Denhardt's solution, $10 \%$ dextran sulfate, $0.5 \mathrm{mg} / \mathrm{ml}$ sheared salmon sperm DNA, $1 \%$ sarcosyl, $0.02 \mathrm{M} \mathrm{NaPO}_{4}$ (pH 7.0), $50 \mathrm{~mm}$ dithiothreitol, and $10^{7} \mathrm{cpm} / \mathrm{ml}$ of probe. After hybridization, the slides were rinsed in five changes of $1 \times \mathrm{SSC}$ at $55^{\circ} \mathrm{C}$, dried, and dipped in emulsion. After 6 weeks exposure at $-20^{\circ} \mathrm{C}$, the slides were developed and counterstained as described above. Silver 

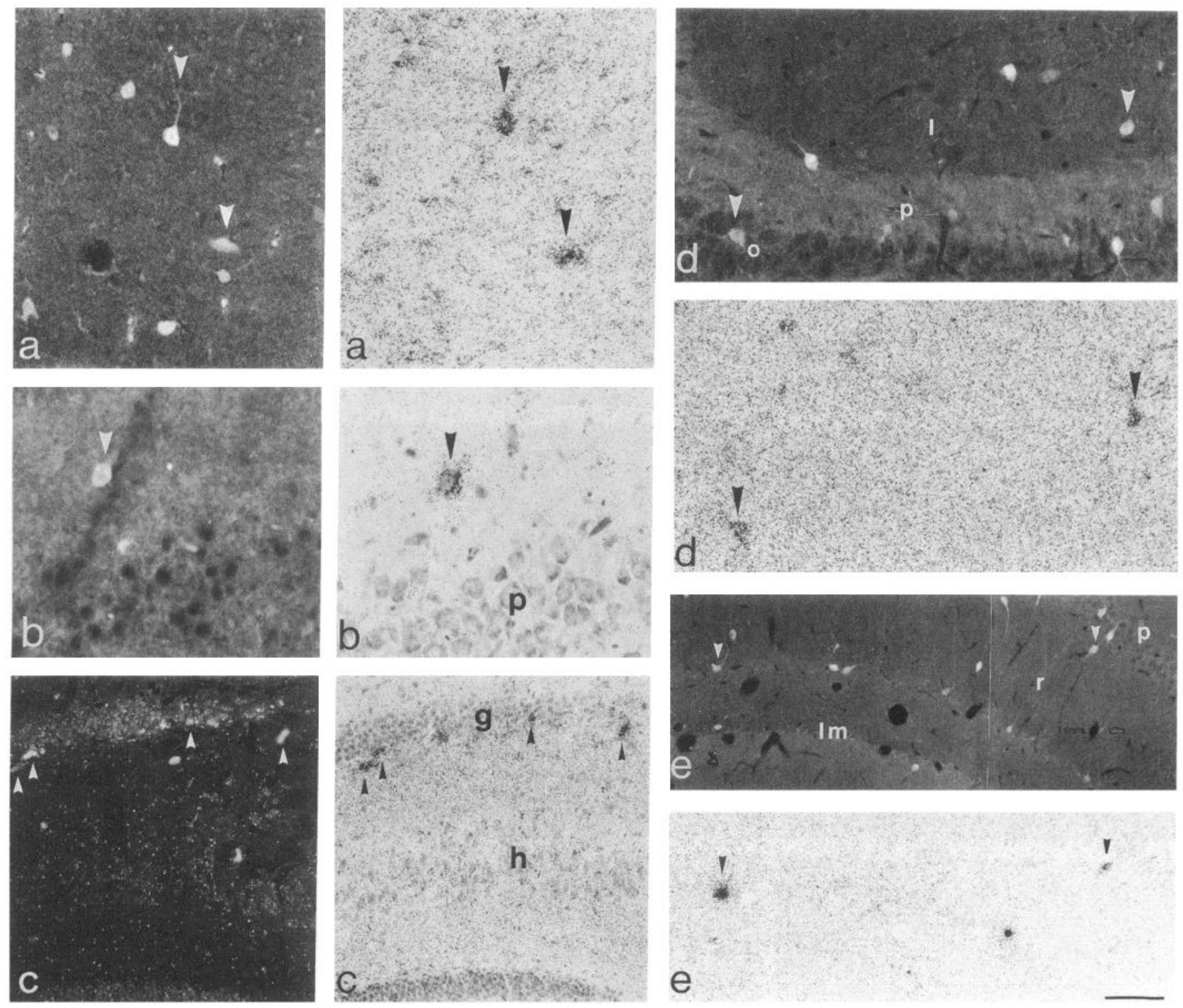

Figure 3. Comparison between neurons with GABA-immunocytochemical reactivity as detected by fluorescence histochemistry (left panels) and ${ }^{125}$ I- $\alpha$-BT labeling. For all panels but $b$, the fluorescence histochemistry was performed on perfused and fixed brain sections, followed by ${ }^{125}$ I- $\alpha$-BT binding. For $b$, the ${ }^{125} \mathrm{I}-\alpha$-BT was injected intraventricularly, and then the brain was perfused, fixed, and sectioned. The section was prepared first for fluorescence histochemistry and then for autoradiography. $a$ and $b$ show large neurons (arrowheads) that contain GABA and also bind $\alpha$-BT, located in the stratum oriens of CA3. Similar CA3 neurons are shown in stratum oriens and stratum lucidum in $d$. $c$ shows a series of smaller neurons on the inner layer of the distal portion of the dorsal blade of the dentate gyrus. $e$ shows several small neurons in CA1, in striatum radiatum, and in stratum lacunosum moleculare. Scale bar: $50 \mu \mathrm{m}$ for $a-d ; 100 \mu \mathrm{m}$ for $e$.

grain densities were quantified in $20 \times$ dark-field images by a computerbased video image analyzer (MAGISCAN, Joyce-Loebl Ltd., Tyne and Wear, UK). For each hippocampal field, three $500 \mu \mathrm{m}^{2}$ regions were identified. A threshold was established that identified grains and rejected the counterstained cell bodies. The same threshold was used for all analyses. MAGISCAN then computed the fraction of area in the region occupied by grains.

\section{Results}

$\alpha$-BT bound extensively to sections of rat hippocampus (Figs. $1,2)$. A similar pattern of binding was observed in both fixed and unfixed tissue, although the amount of binding was greater in unfixed tissue. In vivo binding of $\alpha$-BT after intraventricular administration showed a similar pattern to that observed in vitro in $\mathrm{CA} 1$ and $\mathrm{CA} 3$, but generally failed to reach the dentate gyrus. $\alpha$-BT binding was blocked by $d$-tubocurarine (Fig. $1 b$ ). The binding was most dense in the dentate and more diffuse in Ammon's horn (Fig. 2). In both areas, however, the densest binding was to the cell bodies and principal dendrites of neurons outside the granule cell and pyramidal cell layers. In the dentate these neurons were most often found at the boundaries of the granule cell layer, as well as scattered through the remainder of the hilus (Fig. 2d). Frequently, labeled neurons were found on the interior edge of the dorsal blade of the dentate gyrus, near its lateral end. In CA1, small $\alpha$-BT-labeled neurons are present at the margin of the stratum oriens and the alveus (Fig. $2 b$ ). There were also scattered neurons in stratum pyramidale and stratum lacunosum moleculare.

The largest neurons that were labeled with $\alpha$-BT were found 

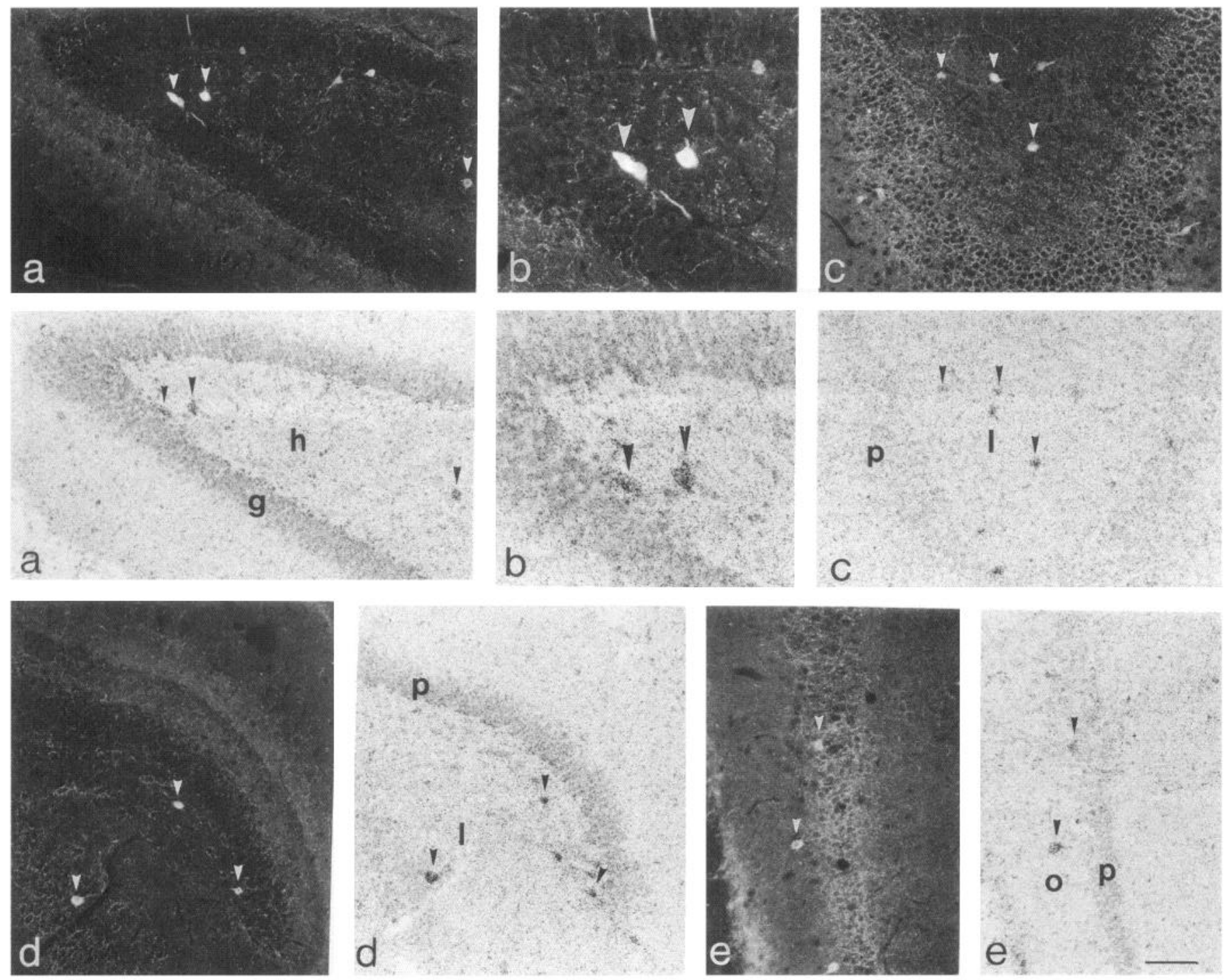

Figure 4. Simultaneous labeling of cells (arrowheads) in fixed brain sections for CCK by fluorescence histochemistry, followed by ${ }^{125}$ I- $\alpha$-BT binding. $a$ and $b$ show labeled cells in the hilus at low and higher magnification. $c$ and $d$ show labeled neurons in CA3, in stratum lucidum. $e$ shows labeled cells in CA2 in stratum oriens and in stratum pyramidale. Scale bar: $50 \mu \mathrm{m}$ for $a, c, d$, and $e ; 100 \mu \mathrm{m}$ for $b$.

in the $\mathrm{CA} 3$ region, in both stratum oriens and stratum lucidum, that is, outside the pyramidal layer or interior to it (Fig. $2 c, e$ ). The cell bodies and principal dendritic branches of these cell bodies were often quite heavily labeled.

\section{Immunocytochemical identification}

To determine the identity of the neurons labeled with $\alpha$-BT, identification of neurochemical content by immunocytochemistry was compared with $\alpha$-BT binding in the same section (Fig. 3). A subpopulation of the neurons reactive with an antibody to GABA were labeled by $\alpha$-BT. Although only about one-fifth of the GABA-immunoreactive neurons were labeled with $\alpha$-BT, very few neurons were labeled with $\alpha$-BT that did not contain GABA immunoreactivity. Thus $\alpha$-BT-labeled neurons appear to be a subset of inhibitory interneurons located throughout the hippocampus, including CA3 (Fig. 3a,b,d), CA1 (Fig. 3e) and the dentate (Fig. $3 c$ ).

Hippocampal interneurons contain several neuropeptides. Immunocytochemistry and $\alpha$-BT binding in the same section were used to determine if $\alpha$-BT binding colocalized with a par- ticular neuropeptide. CCK, somatostatin, and NPY were studied. Overlap between CCK and $\alpha$-BT binding was apparent in large cells in the hilus (Fig. $4 a, b$ ), as well as in stratum lucidum and stratum oriens of the $\mathrm{CA} 2$ and $\mathrm{CA} 3$ region (Fig. $4 c-e$ ). Some of the $\alpha$-BT-labeled cells in the hilus in CA2 and CA 3 were also somatostatin positive (Fig. $5 a, c, d$ ). Somatostatin-positive cells that bound $\alpha$-BT were also prominent in stratum radiatum of CA1 (Fig. 5b). NPY-positive neurons that also bound $\alpha$-BT were most prominent in the boundary between the dentate gyrus and the hilus (Fig. $6 a$ ). The large neurons in stratum oriens of CA3 that bind $\alpha$-BT are also notable for their prominent autofluorescence (Fig. $6 b$ ). Thus, no neuropeptide uniquely defines the $\alpha$-BT population. It should further be noted that, as for GABA itself, $\alpha$-BT binding is found in only a subpopulation of the cells that bind any particular peptide.

\section{Effects of $\alpha-B T$ and other cholinergic drugs on expression of growth factors}

Intraventricular administration of $\alpha$-BT increased expression of NGF in rat hippocampus (Fig. 7). With the hybridization con- 

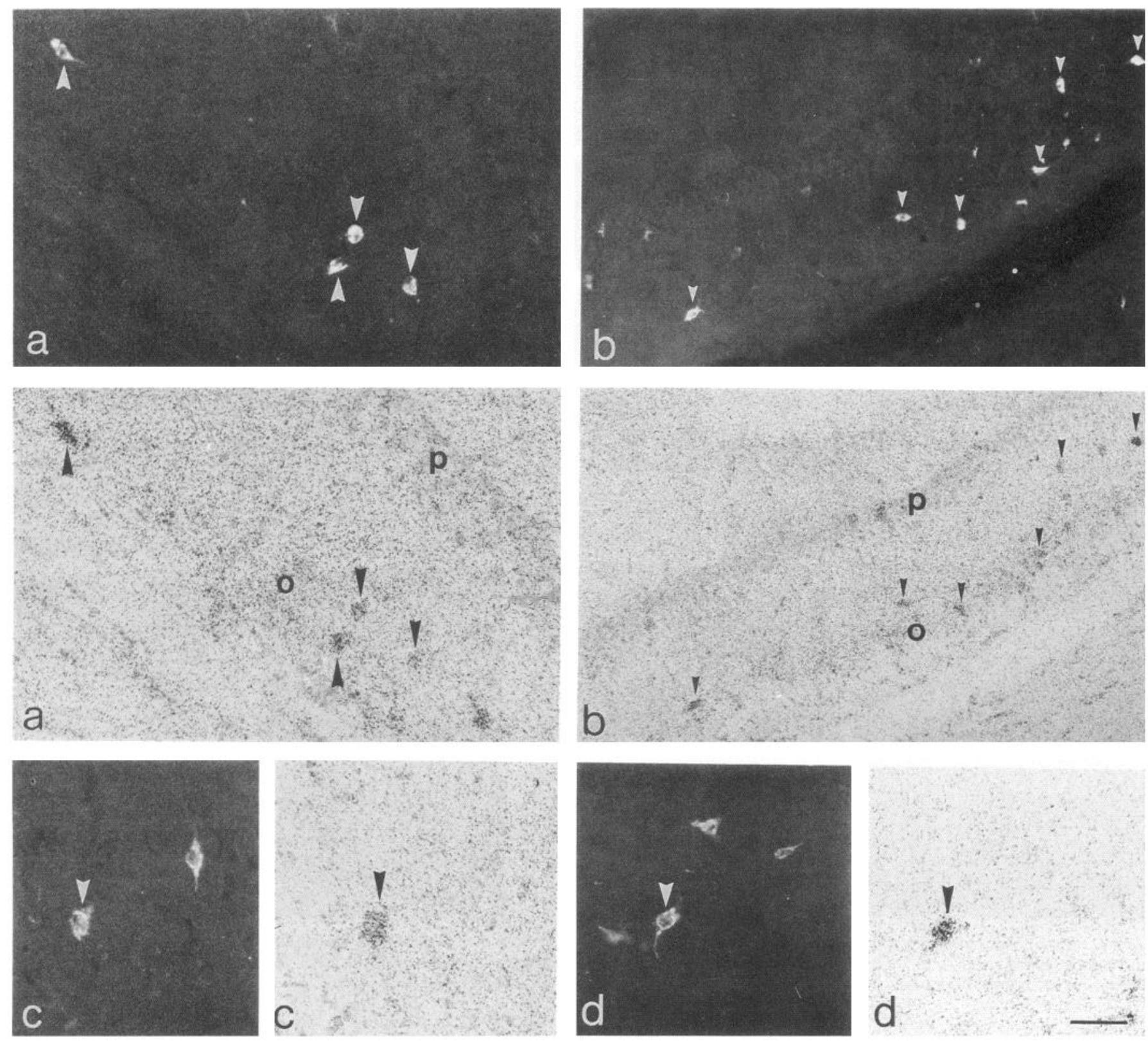

Figure 5. Simultaneous labeling of cells (arrowheads) in fixed brain sections for somatostatin by fluorescence histochemistry, followed by ${ }^{125}$ I- $\alpha$ BT binding. $a$ shows neurons in CA2, stratum oriens. $b$ shows neurons in CA1, stratum oriens. $c$ and $d$ show neurons in CA3, stratum oriens. Scale bar, $50 \mu \mathrm{m}$.

ditions used in this study, NGF expression in control brains was limited to hilar neurons and scattered cells in Ammon's horn. The same pattern was observed in unoperated animals and in those that received injections of Ringer's solution (Fig. $7 b$ ). A similar distribution of expression was seen using these hybridization conditions by Ballarin et al. (1991), in their control specimens. After $\alpha$-BT administration, NGF hybridization increased in both the dentate (Fig. $7 a$ ) and to a lesser extent in Ammon's horn (Table 1). An increased number of hilar cells, many of them putative interneurons near the margin of the granule cell layer, as well as the granule cells themselves, were now labeled. In CA3, cells both within and external to the pyramidal layer were labeled, but most pyramidal neurons were not labeled. There was no increase in labeling in CA1.

BDNF expression also increased after $\alpha$-BT administration
(Figs. 8, 9). BDNF hybridization can be observed in virtually all neurons of the hippocampus in some control animals, with appropriate hybridizations conditions (Wetmore et al., 1991). Hybridization in control animals in this study was limited to scattered cells throughout Ammon's horn (Fig. 8b) and to the hilus (Fig. $8 d$ ). Similar patterns were observed in both unoperated animals and those that received Ringer's solution, as well as in those reported by Ballarin et al. (1991). Reasons for the low basal rate of BDNF expression may include the removal of the brain while the animal was under barbiturate anesthesia and the relatively short autoradiographic exposure used. After $\alpha$-BT administration, there was extensive BDNF hybridization in the hilus and the dentate gyrus (Fig. 8c) and in CA3 (Fig. 8a), encompassing both pyramidal and nonpyramidal neurons. The BDNF labeling in the CA3 pyramidal layer was more extensive 

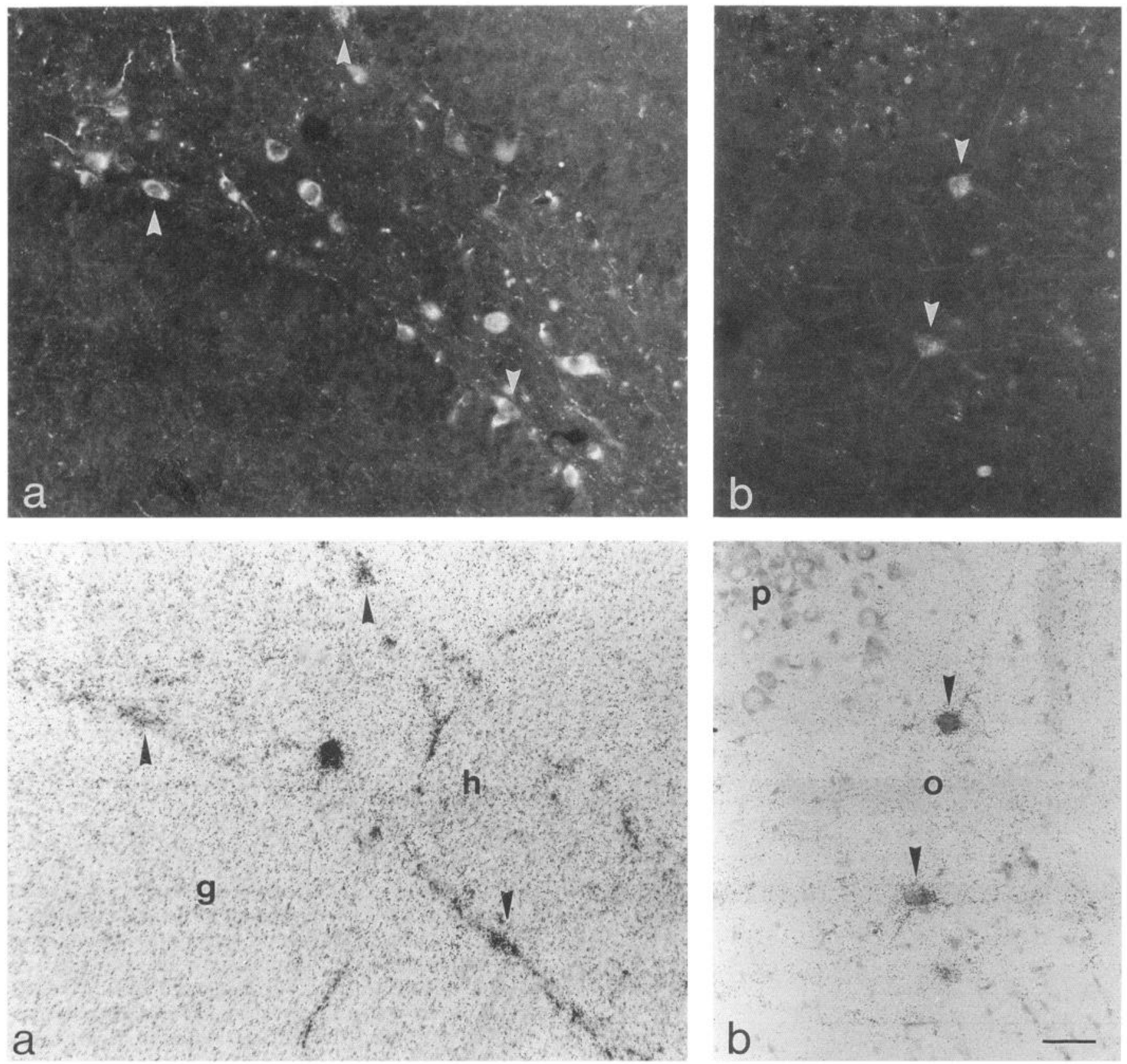

Figure 6. $a$ shows labeling of a fixed section of the dentate gyrus for NPY by fluorescence histochemistry, followed by ${ }^{125}$ I- $\alpha$-BT binding. $b$ shows large neurons in CA3, stratum oriens, which contain autofluorescent fat granules. These cells are also labeled by ${ }^{125} \mathrm{I}-\alpha-\mathrm{BT}$. Scale bar, $25 \mu \mathrm{m}$.

than that observed for NGF. There was no increase in labeling in CA1 (Fig. 9).

For both NGF and BDNF, the increase in expression was bilateral, although increase in expression contralateral to the injection site was significant only for NGF (Table 1). For both growth factors, the increase was greatest in CA3 and the dentate. NT3 expression was limited to CA1 and the subiculum; it did not increase with $\alpha$-BT administration. None of the growth factors increased expression after atropine administration.

\section{Discussion}

$\alpha$-BT binds throughout the hippocampus, but the most heavily labeled structures appear to be GABAergic interneurons in both the dentate gyrus and Ammon's horn. Large interneurons in
CA3 that contain CCK and somatostatin, NPY-positive interneurons in the dentate, and somatostatin-positive interneurons in $\mathrm{CAl}$ comprise the most prominently labeled populations. Only about one-fifth of immunocytochemically defined interneurons bind $\alpha$-BT in significant amounts. However, all major types of hippocampal interneurons appear to be represented among the $\alpha$-BT-labeled group. It is not unexpected that $\alpha$-BT binding is not colocalized with a particular neuropeptide, as the neuropeptides themselves may have overlapping distributions among the interneurons (Sloviter and Nilaver, 1987; Deller and Leranth, 1990).

The large interneurons of CA 3 labeled by $\alpha$-BT may include a group described by Alonso and Kohler (1982). This group of large multipolar neurons, similar in description to the neurons 

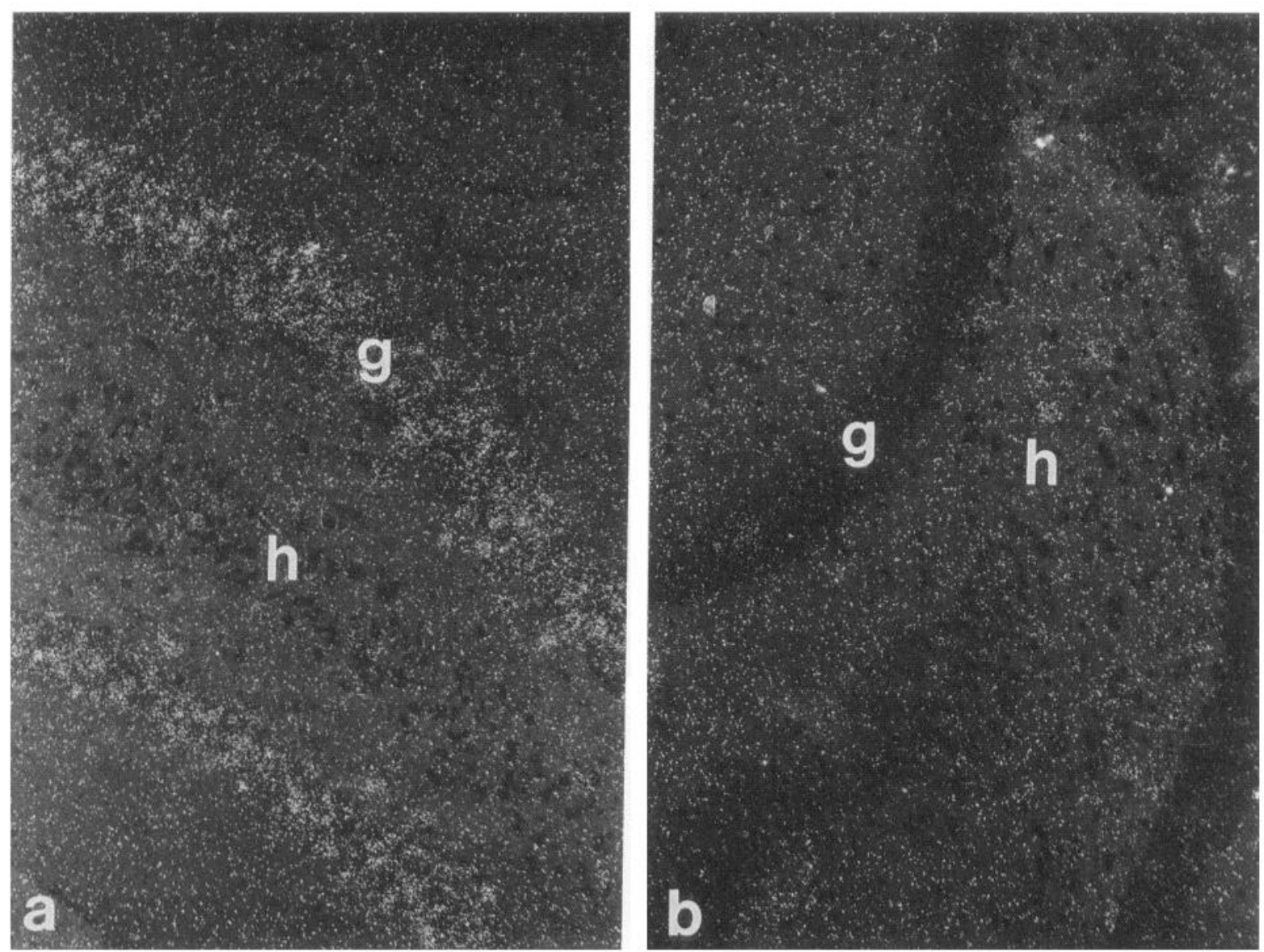

Figure 7. In situ hybridization using a probe for NGF mRNA in rat hippocampus, $3 \mathrm{hr}$ after intraventricular administration of $\alpha$-BT ( $1 \mu \mathrm{g}$ in 10 $\mu \mathrm{l} ; a$ ) or and equal volume of Ringer's solution $(b)$. The animal treated with $\alpha$-BT shows prominent labeling in the dentate $(a)$. The animal treated with Ringer's shows no labeling in the dentate $(b)$, with scattered cells labeled in the hilus.

\begin{tabular}{|c|c|c|c|}
\hline & \multirow[b]{2}{*}{$\begin{array}{l}\text { Control } \\
\text { (Ringer's) }\end{array}$} & \multicolumn{2}{|c|}{$\alpha$-BT $(1 \mu \mathrm{g}$, i.c.v. $)$} \\
\hline & & Ipsilateral & $\begin{array}{l}\text { Contra- } \\
\text { lateral }\end{array}$ \\
\hline \multicolumn{4}{|l|}{ BDNF } \\
\hline \multirow[t]{2}{*}{ Dentate } & 0.033 & 0.670 & 0.731 \\
\hline & 0.037 & 0.635 & 0.672 \\
\hline \multirow{2}{*}{ Hilus } & 0.061 & 0.130 & 0.012 \\
\hline & 0.063 & 0.222 & 0.090 \\
\hline \multirow[t]{2}{*}{$\mathrm{CA} 3$} & 0.099 & 0.370 & 0.282 \\
\hline & 0.096 & 0.734 & 0.379 \\
\hline \multirow[t]{2}{*}{ CAl } & 0.058 & 0.102 & 0.082 \\
\hline & 0.049 & 0.083 & 0.091 \\
\hline \multicolumn{4}{|l|}{ NGF } \\
\hline \multirow[t]{2}{*}{ Dentate } & 0.047 & 0.321 & 0.334 \\
\hline & 0.042 & 0.372 & 0.302 \\
\hline \multirow[t]{2}{*}{ Hilus } & 0.114 & 0.080 & 0.120 \\
\hline & 0.120 & 0.133 & 0.102 \\
\hline \multirow[t]{2}{*}{$\mathrm{CA} 3$} & 0.037 & 0.140 & 0.030 \\
\hline & 0.042 & 0.170 & 0.042 \\
\hline \multirow[t]{2}{*}{ CA1 } & 0.058 & 0.021 & 0.033 \\
\hline & 0.049 & 0.025 & 0.026 \\
\hline
\end{tabular}

shown in Figure $6 b$, projects from stratum oriens and stratum lucidum of CA3 to the medial septal nucleus. Although the major projections of GABAergic neurons in CA3 are thought to be intrahippocampal, these neurons may also exert some inhibitory feedback control over cholinergic input into the hippocampus. This group of neurons has also been shown to receive innervation from the medial septal nucleus, on the basis of transfer of ${ }^{3} \mathrm{H}$-adenosine (Rose and Schubert, 1977).

The existence of a functional role for $\alpha$-BT receptors in the CNS has been debated for some time, because the distribution of $\alpha$-BT binding does not correspond with the distribution of high-affinity nicotine and ACh binding sites (Härfstrand et al., 1988) and because many electrophysiological studies found that the effects of nicotine and ACh were not blocked by $\alpha$-BT (Duggan et al., 1976; Bursztajn and Gershon, 1977). The $\alpha 3$ and $\alpha 4$ receptor subunits also do not form $\alpha$-BT-sensitive receptors in oocytes (Boulter et al., 1987). Recently, however, several studies

Each value is the mean of three grain density determinations over a $500 \mu \mathrm{m}^{2}$ area, expressed as fraction of the area occupied by grains; values from two animals are shown. ANOVA showed a significant effect of treatment on hybridization of probes for both BDNF $(F=10.2 ; \mathrm{df} 1,3 ; p<0.05)$ and NGF mRNA $(F=32.8$; df 1,3 ; $p<0.05)$ in the hippocampus ipsilateral to the ventricle used for administration. There were significant contralateral effects only for NGF $(F=70.6$; df 1,$3 ; p<$ $0.05)$. There were no significant effects for hippocampal region, which was used as a nested factor in the ANOVA. 

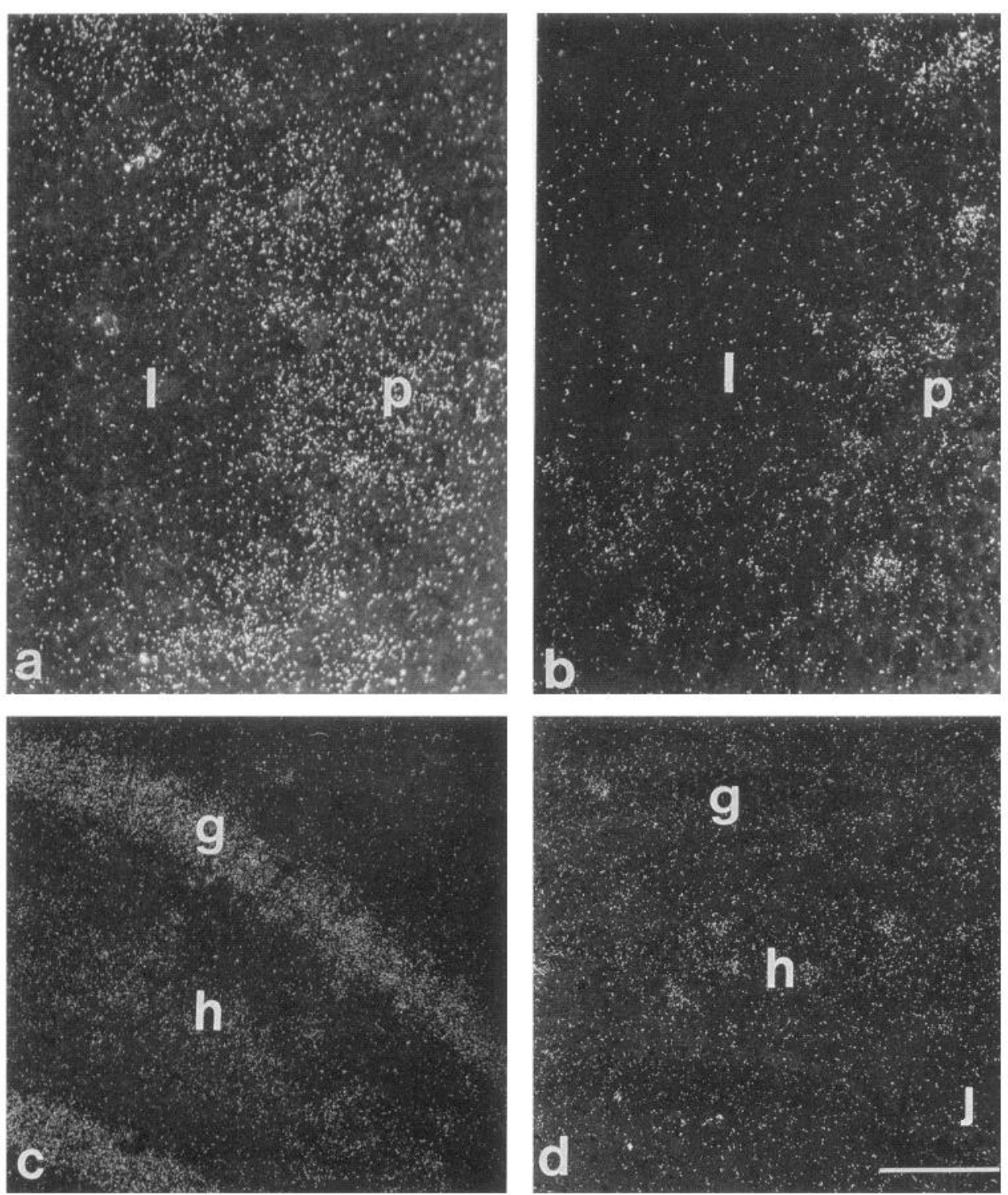

Figure 8. In situ hybridization of BDNF mRNA in rat hippocampus, 3 $\mathrm{hr}$ after intraventricular administration of $\alpha$-BT ( $1 \mu \mathrm{g} ; a, c)$ or Ringer's solution $(b, d) . \alpha$-BT administration caused an increased binding in $\mathrm{CA} 3(a)$ and in the dentate gyrus and hilus $(c)$. Ringertreated animals showed only scattered cells labeled in CA3 $(b)$ and in the hilus $(d)$, with little labeling in the dentate. Scale bar, $100 \mu \mathrm{m}$. have shown blockade by $\alpha$-BT of effects of ACh and nicotine on inhibitory interneurons in the cerebellum (de la Garza et al., 1987), as well as a role for $\alpha$-BT in the physiology of the CA3 region in the hippocampus (Marks et al., 1989; Luntz-Leybman et al., 1992). The expression of the $\alpha 7$ subunit in oocytes further supports a functional role for the $\alpha$-BT-binding protein (Couturier et al., 1990). The effects of $\alpha$-BT-sensitive receptors may have been obscured in other regions by their coexistence with other nicotinic receptors. In isolated gene expression systems, the function of the $\alpha$-BT-sensitive $\alpha 7$ nicotinic receptor subunit can be obscured by coexpression of the $\alpha 3$ receptor (Listerud et al., 1991). Although in situ hybridization suggests that $\alpha 7$ is expressed throughout the hippocampus (Johnson et al., 1991), $\alpha 3$ is also expressed in some areas, particularly in CA1 (Wada et al., 1989).

The increase in BDNF and NGF expression after $\alpha$-BT administration is further evidence for a functional effect of $\alpha$-BTsensitive receptors. BDNF and NGF expression increase in the hippocampus after a variety of treatments, including kindling and treatment with excitants (Gall and Issackson, 1989; Ballarin et al., 1991). In those experiments, expression increased in the dentate and throughout Ammon's horn. In the experiments with $\alpha$-BT reported here, the increase in expression was principally in CA 3 and the dentate gyrus. This finding suggests that $\alpha$-BT does not nonspecifically excite the hippocampus, but rather acts primarily in CA3 and the dentate, where the cholinergic septal innervation is greatest. Furthermore, within the dentate, the increase in expression of growth factors is greatest in the upper blade, where $\alpha$-BT-binding interneurons are concentrated. CA3 is the area where physiological effects sensitive to $\alpha$-BT have been reported (Miner and Collins, 1989; Luntz-Leybman et al., 1992). By contrast, electrophysiological effects of nicotine in CA1 are not blocked by $\alpha$-BT (Freund et al., 1990). It is possible that the coexistence of $\alpha 3$ subunits in some CA1 cells may obscure the effects of $\alpha$-BT-sensitive receptors, as in the singlecell expression systems described above.

The increased expression of mRNA for NGF and BDNF was not limited to interneurons that bound $\alpha$-BT, but rather was prominent in the CA3 pyramidal cell layer and the dentate granules cells as well, where $\alpha$-BT binding itself is less intense. The finding of increased growth factor expression throughout the hippocampus after treatment with excitants such as kainic 


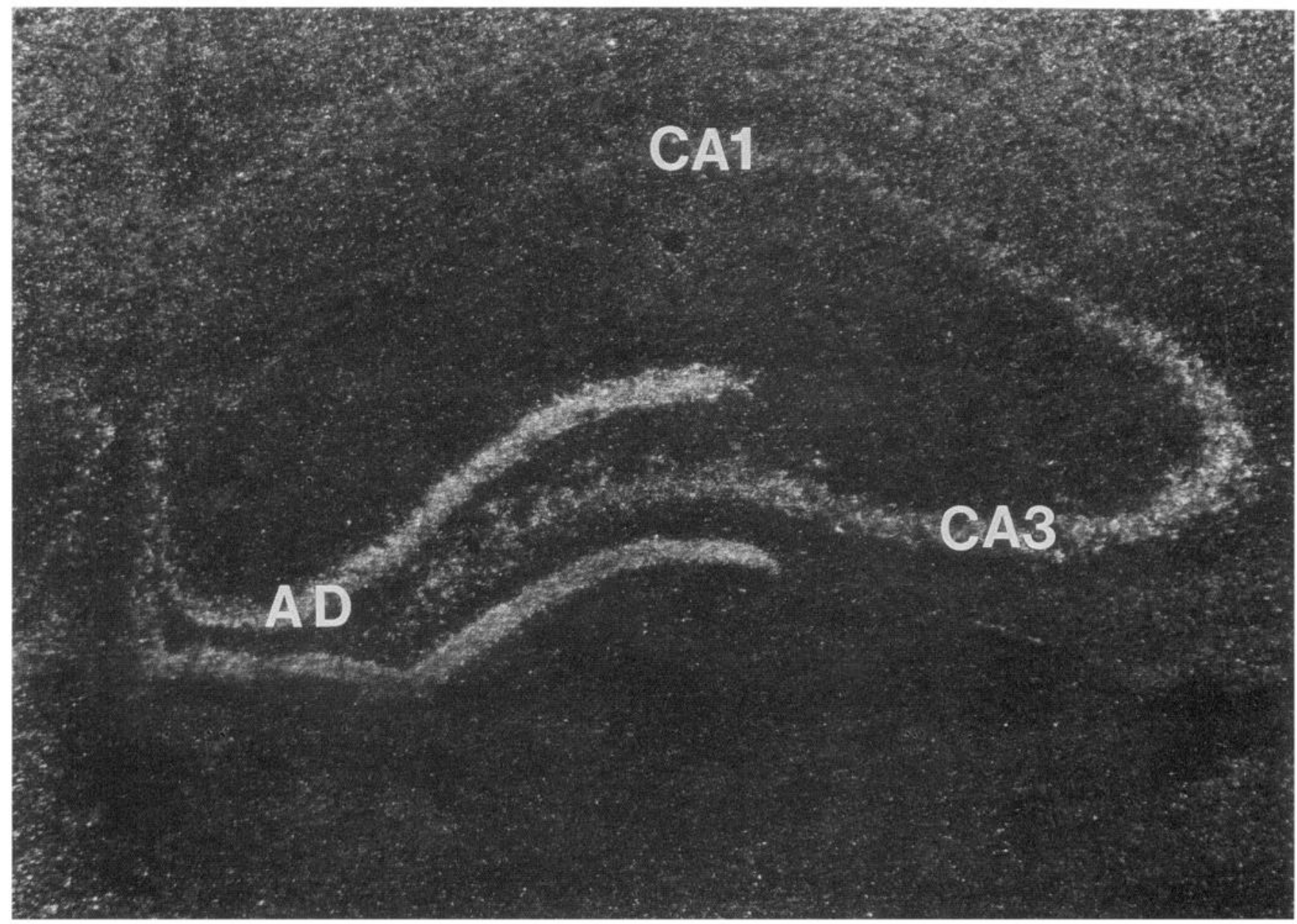

Figure 9. In situ hybridization of BDNF mRNA $3 \mathrm{hr}$ after ipsilateral intraventricular administration of $\alpha$-BT (1 $\mu \mathrm{g})$. Labeling is most prominent in the $C A 3$ and the area dentata $(A D)$ layers, and clearly less in $C A 1$. The dorsal blade of the dentate gyrus is more prominently labeled than the inferior blade.

acid suggests that such increase may occur whenever hippocampal neurons are stimulated. Blockade of the cholinergic input to selected interneurons in the hippocampus by $\alpha$-BT may be sufficient to excite the dentate granule cells and the CA3 pyramidal cells and thus to produce the increase pattern of expression observed. Excitation is commonly observed when interneuronal function is antagonized (Schwartzkroin, 1986). Receptors on the pyramidal neurons themselves might also be responsible (Hunt and Schmidt, 1978). Although $\alpha$-BT delivered intraventricularly primarily binds in the ipsilateral hippocampus, effects on growth factor expression were observed bilaterally. This finding is consistent with the commissural connections between $\mathrm{CA} 3$ and the dentate, which would support bilateral excitation even if only one side were affected by $\alpha$-BT. The NPY-containing interneurons of the dentate are also known to have such connections (Deller and Leranth, 1990), as well as the CA3 pyramidal neurons themselves. Furthermore, although the data are consistent with the action of $\alpha$-BT on hippocampal receptors, actions of $\alpha$-BT elsewhere in the brain after intraventricular administration are also possible.

It is noteworthy that $\alpha$-BT increased growth factor expression but atropine, a muscarinic antagonist, did not. Measurement of NGF protein in hippocampus and mRNA in cortex has also shown no effect of muscarinic antagonism on growth factor expression (Alberch et al., 1991). $\alpha$-BT-sensitive receptors may therefore have a unique role in regulating hippocampal physiology, not shared by other types of cholinergic receptors. Furthermore, nicotinic receptors on interneurons may be a common mechanism in the CNS. In addition to the innervation of the hippocampal interneurons observed here, there are nicotinic synapses reported on interneurons in the cerebellum and the retina (de la Garza et al., 1987; Hamassakibritto et al., 1991).

\section{References}

Alberch J, Carman-Krzan M, Fabrazzo M, Wise BC (1991) Chronic treatment with scopolamine and physostigmine changes nerve growth factor (NGF) receptor density and NGF content in rat brain. Brain Res 542:233-240.

Alonso A, Kohler C (1982) Evidence for separate projections of hippocampal pyramidal and non-pyramidal neurons to different parts of the septum in the rat brain. Neurosci Lett 31:209-214.

Ayer-LeLievre C, Olson L, Ebendal T, Seiger A, Persson H (1988) Expression of the $\beta$-nerve growth factor gene in hippocampal neurons. Science 240:1339-1341.

Ballarin M, Ernfors P, Lindefors N, Persson H (1991) Hippocampal damage and kainic acid injection induce a rapid increase in mRNA for BDNF and NGF in the rat brain. Exp Neurol 114:35-43.

Bickford-Wimer PC, Nagamoto H, Johnson R, Adler LE, Egan M, Rose GM, Freedman R (1990) Auditory sensory gating in hippocampal neurons: a model system in the rat. Biol Psychiatry 27:183-192.

Boulter J, Connolly J, Deneris E, Goldman D, Heinemann S, Patrick J 
(1987) Functional expression of two neuronal nicotinic acetylcholine receptors from cDNA clones identifies a gene family. Proc Natl Acad Sci USA 84:7763-7767.

Bursztajn S, Gershon MD (1977) Discrimination between nicotinic receptors in vertebrate ganglia and skeletal muscle by alpha-bungarotoxin and cobra venoms. J Physiol (Lond) 269:17-31.

Clarke PBS, Schwartz RD, Paul SM, Pert C, Pert A (1985) Nicotine binding in rat brain: autoradiographical comparison of $\left[{ }^{3} \mathrm{H}\right]$-acetylcholine, $\left[{ }^{3} \mathrm{H}\right]$-nicotine and $\left[{ }^{125} \mathrm{I}\right]$-alpha-bungarotoxin. J Neurosci 5:1307-1315.

Couturier S, Bertrand D, Matter JM, Hernandez MC, Bertrand S, Millar N, Valera S, Barkas T, Ballivet M (1990) A neuronal nicotinic acetylcholine receptor subunit (alpha 7) is developmentally regulated and forms a homo-oligomeric channel blocked by alpha-BTX. Neuron 5:847-856.

de la Garza R, McGuire TJ, Freedman R, Hoffer BJ (1987) Selective antagonism of nicotine actions in the rat cerebellum with $\alpha$-bungarotoxin. Neuroscience 23:887-891.

Deller T, Leranth C (1990) Synaptic connections of neuropeptide $Y$ (NPY) immunoreactive neurons in the hilar area of the rat hippocampus. J Comp Neurol 300:433-447.

Duggan AW, Hall JG, Lee CY (1976) Alpha-bungarotoxin, cobra neurotoxin and excitation of Renshaw cells by acetylcholine. Brain Res 107:166-170.

Ernfors P, Ibáñez CF, Ebendal T, Olson L, Persson H (1990) Molecular cloning and neurotrophic activities of a protein with structural similarities to nerve growth factor: developmental and topographical expression in the brain. Proc Natl Acad Sci USA 87:5454-5458.

Freund RK, Jungschaffer DA, Collins AC (1990) Nicotine effects in mouse hippocampus are blocked by mecamylamine, but not other nicotinic antagonists. Brain Res 511:187-191.

Frotscher M, Leranth C (1985) Cholinergic innervation of the rat hippocampus as revealed by choline acetyltransferase immunocytochemistry. J Comp Neurol 239:237-246.

Fuchs JL (1989) $\left.{ }^{125} \mathrm{I}\right] \alpha$-Bungarotoxin binding marks primary sensory areas of developing rat neocortex. Brain Res 501:223-234.

Gall CM, Isackson PJ (1989) Limbic seizures increase neuronal production of messenger RNA for nerve growth factor. Science 245:758761

Green RC, Blume HW, Kupferschmid SB, Mesulam MM (1989) Altcrations of hippocampal acetylcholinesterase in human temporal lobe epilepsy. Ann Neurol 26:347-351.

Hamassakibritto A, Brzozowskaprechtl A, Karten HJ, Lindstrom JM, Keyser KT (1991) GABA-like immunoreactive cells containing nicotinic acetylcholine receptors in the chick retina. J Comp Neurol 313: $394-401$.

Härfstrand A, Adem A, Fuxe K, Agnati L, Andersson K, Nordberg A (1988) Distribution of nicotinic cholinergic receptors in the rat teland diencephalon: a quantitative receptor autoradiographical study using $\left[{ }^{3} \mathrm{H}\right]$-acetylcholine, $\left[\alpha-{ }^{125} \mathrm{I}\right]$ bungarotoxin and $\left[{ }^{3} \mathrm{H}\right]$ nicotine. Acta Physiol Scand 132:1-14.

Hunt SP, Schmidt J (1978) The electron microscopic autoradiographic localization of alpha-bungarotoxin binding sites within the central nervous system of the rat. Brain Res 142:152-159.

Johnson DS, Stroessner-Johnson HM, Boulter J, Amaral DG, Heinemann S (1991) Distribution of alpha7 neuronal nicotinic receptor mRNA in the rat CNS. Soc Neurosci Abstr 17:249.

Joyce JN, Gibbs RB, Cotman CW, Marshall JF (1989) Regulation of muscarinic receptors in hippocampus following cholinergic denervation and reinnervation by septal and striatal transplants. J Neurosci 9:2776-2791.

Kohler C, Chan-Palay V (1982) Somatostatin-like immunoreactive neurons in the hippocampus: an immunocytochemical study in the rat. Neurosci Lett 34:259-264.
Korsching S, Auburger G, Heumann R, Scott J, Thoenen H (1985) Levels of nerve growth factor and its mRNA in the central nervous system of the rat correlate with cholinergic innervation. Eur Mol Biol Org J 4:1389-1393.

Lippa AS, Pelhman RW, Beer B, Critchett DJ, Dean RL, Bartus RT (1980) Brain cholinergic dysfunction and memory in aged rats. Neurobiol Aging 1:13-19.

Listerud M, Brussaard AB, Devay P, Colman DR, Role LW (1991) Functional contribution of neuronal AChR subunits revealed by antisense oligonucleotides. Science 254:1518-1521.

Luntz-Leybman V, Bickford P, Freedman R (1992) Cholinergic gating of response to auditory stimuli in rat hippocampus. Brain Res 587: 130-136.

Marks MJ, Romm E, Campbell SM, Collins AC (1989) Variation of nicotinic binding sites among inbred strains. Pharmacol Biochem Behav 33:679-689.

Miner LL, Collins AC (1989) Strain comparison of nicotine-induced seizure sensitivity and nicotinic receptors. Pharmacol Biochem Behav 33:469-475.

Pauly JR, Stitzel JA, Marks MJ, Collins AC (1989) An autoradiographic analysis of cholinergic receptors in mouse brain. Brain Res 22:453-459.

Phillips HS, Hains JM, Laramee GR, Rosenthal A, Winslow JW (1990) Widespread expression of BDNF but not NT3 by target areas of basal forebrain cholinergic neurons. Science 250:290-294.

Rose G, Schubert P (1977) Release and transfer of $\left[{ }^{3} \mathrm{H}\right]$ adenosine derivatives in the cholinergic septal system. Brain Res 121:353-357.

Schulz DW, Loring RH, Aizenman E, Zigmond RE (1991) Autoradiographic localization of putative nicotinic receptors in the rat brain using ${ }^{125}$ I-neuronal bungarotoxin. J Neurosci 11:287-297.

Schwartzkroin PA (1986) Regulation of excitability in hippocampal neurons. In: The hippocampus, Vol 3 (Issacson RL, Pribram KH, eds), pp 113-136. New York: Plenum.

Segal M, Dudai Y, Amsterdam A (1978) Distribution of $\alpha$-bungarotoxin-binding cholinergic nicotinic receptor in rat brain. Brain Res 148:105-119.

Sequala P, Geffard M, Buijs RM, LeMoal M (1984) Antibodies against gamma amino butyric acid: specificity studies and immunocytochemical results. Proc Natl Acad Sci USA 81:3888-3892.

Sloviter RS, Nilaver G (1987) Immunocytochemical localization of GABA-, cholecystokinin-, vasoactive intestinal polypeptide-, and somatostatin-like immunoreactivity in the area dentata and hippocampus of the rat. J Comp Neurol 256:42-60.

Vanderwolf $\mathrm{CH}$ (1975) Neocortical and hippocampal activation in relation to behavior. J Comp Physiol Psychol 88:300-323.

Vinogradova $O$ (1975) Functional organization of the limbic system in the process of registration of information: facts and hypotheses. In: The hippocampus: neurophysiology and behavior, Vol 2 (Issacson RL, Pribram KH, eds), pp 1-70. New York: Plenum.

Wada E, Wada K, Boulter J, Deneris E, Heinemann S, Patrick J, Swanson LW (1989) Distribution of alpha2, alpha3, alpha4, and beta2 neuronal nicotinic receptor subunit mRNAs in the central nervous system: a hybridization histochemical study in the rat. J Comp Neurol 284:314-335.

Wetmore C, Cao Y, Pettersson RF, Olson L (1991) Brain-derived neurotrophic factor: subcellular compartmentalization and interneuronal transfer as visualized with anti-peptide antibodies. Proc Natl Acad Sci USA 88:9843-9847.

Whittemore SR, Friedman PL, Larhammar D, Persson H, GonzalezCarvajal M, Holets VR (1988) Rat $\beta$-nerve growth factor sequence and site of synthesis in the adult hippocampus. J Neurosci Res 20: $403-410$. 